\title{
Study on Prevalence of Mycoflora in Wheat Seeds
}

\author{
Pratishtha Adhikari $^{1}$, Gopal Bahadur Khatri-Chhetri ${ }^{1}$, Sundar Man Shrestha ${ }^{1}$, \\ Santosh Marahatta ${ }^{2}$
}

${ }^{1}$ Institute of Agriculture and Animal Sciences, Tribhuvan University, Nepal

${ }^{2}$ Agriculture and Forestry University, Nepal

A R T I C LE IN F O

Article history:

Received 07 July 2015

Accepted 01 December 2015

Available online, ISSN: 2148-127X

Keywords:

Wheat

Variety

Genotypes

Blotter test

Pathogen

${ }^{*}$ Corresponding Author:

E-mail: adhikari_pk@yahoo.com \begin{abstract}
A B S T R A C T
Forty seed sample of wheat (Triticum aestivum) were collected from four locations viz. Chitwan, Kaski, Banke and Lalitpur and tested by blotter method at laboratory during 2013 for determining fungal pathogens associated with wheat seeds in Nepal. Eighteen species representing thirteen genera of fungi were recovered from the seed. Alternaria alternata and Bipolaris sorokiniana were predominant in all the varieties/genotypes from all the locations, where $B$. sorokiniana was strongly pathogenic in wheat crop. Percentage frequency and type of fungi detected varied with variety and locations. Bipolaris sorokiniana was highest $(64.40 \%)$ in Banke than remaining three locations. Seeds of Chitwan had lowest percentage (5.50\%) of seed infection as compared to other locations. Relative abundance of Alternaria alternata $(55.10 \%)$ was highest as it was the most prevalent component of seed borne mycoflora, followed by Bipolaris sorokiniana (34.69\%) and Cladosporium herbarum (7.19\%). Differences in quantity of precipitation and relative humidity might be the possible reason for variation in frequency and type of fungi detected in wheat seeds of four locations.
\end{abstract}

\section{Introduction}

Wheat is third most important cereal crop in Nepal in terms of area (760,000.0 ha) and production (1,882,000.0 $\mathrm{mt}$ ) with productivity of 2.47 ton per hectare (MOAD, 2013). It is the major winter cereal grown from terai (plain area) to hills, and share of terai to the total area and production of nation is $59.3 \%$ and $69.3 \%$, respectively (Khanal et al., 2012). Annual average increase in wheat production is $10 \%$, however, in 2012/13; a marginal increment of $2 \%$ was recorded. Seed is one of the important inputs for cultivation, as it determines potential production and productivity of the crops (Friis-Hansen, 1995).

There are several factors limiting wheat yield. Among them diseases incidence and their poor management is one of the important factors in Nepal (Rosyara, 2002). Seed may be passive carrier of pathogens. Seeds infected by pathogens in the field may survive and become sources of primary inoculum in the next generation. They may cause seed abortion, seed rot, seed necrosis, reduction or elimination of germination as well as seedling damage resulting in development of disease at later stages of plant growth by systemic or local infections (Khanzada et al., 2002; Bateman and Kwasna, 1999). Some common seed borne fungi isolated from wheat seeds were Absidia sp., Alternaria alternata, Aspergillus sp., A. candidus, A. flavus, A. niger, A.sulphureus, Cephalosprium sp., Chaetomium globosum, Cladosporium herbarum, Curvularia lunata, Drechslera halodes, D. hawaiiensis,
D. tetramera, Fusarium moniliforme, F. oxysporum, F. pallidoroseum, F. subglutinans, Penicillium spp., Rhizoctonia solani and Rhizopus sp. (Fakhrunnisa and Ghaffar, 2006). These pathogens also affect grain quality and human health. Barabara et al. (2004) reported quality and nutritional composition of wheat reduced by fungal infection. Glutein content in fusarious wheat was lower in comparison to healthy wheat seeds (Dexter et al., 1996).

Pathogen free seeds are vital to have desired germination, emergence, healthy seedlings and plant population. Early identification of seed borne pathogens is important for timely management of diseases and to avoid epidemics. The objective of seed health testing is to identify the healthy and pure seeds that can be sown in the field, which ultimately results in production of healthy food, healthy seed crops, and improved yields in terms of quality and quantity. Early identification of seed borne pathogens allows timely management of diseases and helps to avoid epidemics (Nafula, 1997). It is also essential to carry out seed health testing to check the spread of many seed borne diseases to new areas. The unrestricted movement and exchange of germplasm are vital for the process in crop improvement programs, but the movement of germplasm may result also in spread of diseases (Warham et al., 1996). The present study was carried out to identify fungi prevailing in wheat seeds used commonly in Nepal. 


\section{Materials and Methods}

The study was carried out in mycology laboratory of Seed Quality Control Centre, Hariharbhawan, Lalitpur, Nepal, during August to December, 2013. 200 grams each of 40 sample of wheat were collected from 4 research institutes (10 varieties/genotypes each from Lalitpur, Chitwan, Kaski and Banke) of Nepal (Table 1) for the study. Isolation and identification of seed borne fungi were done by blotter method described by International Seed Testing Association (Mathur and Kongsdal, 2003). Plastic petri-dishes were cleaned by washing with detergent solution and rinsing with tap water, and finally sterilized by just dipping in $4 \% \mathrm{NaOCl}$. Three layers of blotting paper were placed in the labeled, plastic petridishes and moistened with distilled water.

Twenty five seeds per petri-dish were placed in equidistance, fifteen seeds in outer ring, nine in middle ring and one at the center. One hundred seeds formed one replication and four replications were maintained per variety/genotype. The petri-dishes were incubated at $20^{\circ} \mathrm{C}$ under alternate cycles of 12 hours near ultra violet light and darkness. Five, seven and nine days after incubation, the seeds were observed under stereo-binocular microscope for presence/absence of fungi. A binocular, compound microscope was used for identification of fungi. Identification was done based on morphology of spores and mycelia as described by Mathur and Kongsdal (2003).

Percentage frequency (PF) and relative abundance (RA) of fungi were calculated by using the following formula (Naqvi et al., 2013):

$$
\begin{aligned}
& \mathrm{PF}=\frac{\text { No. of seeds on which fungus appears }}{\text { Total number of seeds }} \times 100 \\
& \mathrm{RA}=\frac{\text { No.of a particular fungi }}{\text { Total no.of all fungi }} \times 100
\end{aligned}
$$

Table 1 List of wheat varieties/genotypes collected from four locations.

\begin{tabular}{c|llll}
\hline S.No. & Lalitpur & Chitwan & Kaski & Banke \\
\hline 1 & Bijaya: variety & BL 4009: genotype & Tribeni: variety & NL 1171: genotype \\
2 & RR 21: variety & NL 1191: genotype & BL 4061: genotype & NL 1177: genotype \\
3 & Pasang Lhamu: variety & BL 4461: genotype & Nepal 297: variety & NL 1093: genotype \\
4 & Annapurna 1: variety & Bhrikuti variety & Annapurna 2: variety & BL 4361: genotype \\
5 & Annapurna 4: variety & Bijaya: variety & Lumbini: variety & BL 4350: genotype \\
6 & Achyut: variety & Aditya: variety & Annapurna 1: variety & BL 4341: genotype \\
7 & Nepal 297: variety & NL 1097: genotype & NL 1078: genotype & NL 1164: genotype \\
8 & Bhrikuti: variety & Gautam: variety & Achyut: variety & Bhrikuti: variety \\
9 & Gautam: variety & BL 3599: genotype & Gautam: variety & BL 3978: genotype \\
10 & WK 1204: variety & NL 1094; genotype & Kanti: variety & BL 4347: genotype \\
\hline
\end{tabular}

\section{Results and Discussion}

The study detected a total of thirteen genera and eighteen species of fungi in seeds of forty wheat seed samples. Percentage frequency of Alternaria alternata was highest, followed by Bipolaris sorokiniana and Cladosporium herbarum on seeds of four locations. Alternaria alternata and Bipolaris sorokiniana were predominant among all the fungi detected in wheat seeds. Clear and Patrick'Can (1993) reported 35 fungal genera with 59 species from wheat grain samples with the important genera Alternaria, Bipolaris sorokiniana, Fusarium graminearum, Aspergillus, Cladosporium, Epicoccum, Nigrospora and Septoria nodorum.

Presence of fungi in seeds varied with varieties/genotypes and location. Lowest percentage frequency was found in the genotype BL 4009 (3.06\%) from Chitwan and highest in BL 1177 (16.40\%) from Banke (Table 2, 4). Among varieties, minimum percentage frequency appeared in Nepal 297 (6.25\%) from Kaski and maximum in Gautam (13.25\%) from Lalitpur (Table 3, 5).

Several fungi appeared to be associated with wheat seeds used in various locations. Frequency of Bipolaris sorokiniana appeared lowest in Lalitpur (16.68\%), followed by Chitwan (18.93\%), Kaski (24.57\%) and Banke $(64.40 \%)$, while relative abundance was minimum in Lalitpur (13.32\%), accompanied by Kaski (17.20\%), Chitwan (32.40\%) and Banke (34.69\%), with a mean frequency and relative abundance of $29.83 \%$ and $24.40 \%$, respectively (Table 6). The result showed that the seeds from Banke and Chitwan were highly infected with $B$. sorokiniana, but the seeds also from other locations were not safe with regard to the pathogen. Higher incidence of B. sorokiniana would be due to higher mean temperature and relative humidity in Banke $\left(20.61^{\circ} \mathrm{C}\right.$ and $\left.93.30 \%\right)$ and Chitwan $\left(16.32^{\circ} \mathrm{C}\right.$ and $\left.93.97 \%\right)$ than in Lalitpur $\left(14.54^{\circ} \mathrm{C}\right.$ and $72.44 \%$, respectively). Temperature in Kaski was $14.30^{\circ} \mathrm{C}$, but relative humidity was not available. Saari (1998) reported that high temperature with high relative humidity at the growing period of wheat results in the spot blotch disease. Alam and Saha (1991) mentioned that infection of seed depends upon the prolonged wet weather just before the harvest or high relative humidity with frequent rains at grain filling period. Pickett and Pruitt (2010) reported that continuous cultivation of the same kind of crop leads to build up of pathogens. 
Table 2 Percentage frequency of fungi in seeds of 10 wheat varieties/genotypes from Chitwan

\begin{tabular}{l|ccccccccccccc}
\hline V/G & AA & BS & RS & AF & BiS & CL & PS & EN & AN & FM & CH & FG & Mean \\
\hline BL 4009 & 13.75 & 10.50 & 0.00 & 6.75 & 2.25 & 1.50 & 0.00 & 0.00 & 1.50 & 0.50 & 0.00 & 0.00 & 3.06 \\
BL 3599 & 19.25 & 13.75 & 7.00 & 5.00 & 0.50 & 1.00 & 0.00 & 0.00 & 0.00 & 0.00 & 0.00 & 0.00 & 3.88 \\
BL 4461 & 13.75 & 19.00 & 6.25 & 5.25 & 4.50 & 2.50 & 0.00 & 0.00 & 0.00 & 0.25 & $0.00^{\mathrm{b}}$ & 0.00 & 4.29 \\
NL 1097 & 17.00 & 27.00 & 10.25 & 8.50 & 2.00 & 0.00 & 0.00 & 0.00 & 0.00 & 0.00 & 0.00 & 0.00 & 5.40 \\
NL 1094 & 29.75 & 9.25 & 6.50 & 7.00 & 7.25 & 2.25 & 0.00 & 3.75 & 0.75 & 0.00 & 0.00 & 0.00 & 5.54 \\
Bijaya & 24.00 & 17.75 & 4.25 & 7.50 & 4.50 & 1.25 & 6.75 & 0.50 & 0.00 & 0.00 & 0.00 & 0.25 & 5.56 \\
NL 1191 & 44.25 & 20.00 & 3.00 & 0.00 & 8.25 & 0.00 & 0.00 & 1.50 & 0.00 & 0.00 & 0.00 & 0.00 & 6.42 \\
Bhrikuti & 26.00 & 29.75 & 11.25 & 9.75 & 2.25 & 1.00 & 0.00 & 0.00 & 0.00 & 0.00 & 0.75 & 0.00 & 6.73 \\
Gautam & 33.25 & 21.75 & 9.50 & 8.00 & 4.75 & 2.25 & 0.00 & 0.00 & 1.25 & 0.25 & 0.00 & 0.00 & 6.75 \\
Aditya & 40.25 & 20.50 & 8.50 & 4.00 & 8.75 & 3.00 & 0.00 & 0.75 & 2.50 & 0.00 & 0.00 & 0.00 & 7.35 \\
\hline
\end{tabular}

V/G: Varieties/genotypes, AA: Alternaria alternata, BS: Bipolaris sorokiniana, RS: Rhizopus spp., AF: Aspergillus flavus, BiS: Bipolaris spicifera, CL: Curvularia lunata, PS: Penicillium spp., EN: Epicoccum nigrum, AN: Aspergillus niger, FM: Fusarium moniliforme, CH: Cladosporium herbarum, FG: Fusarium graminearum

Table 3 Percentage frequency of fungi in seeds of 10 wheat varieties/genotypes from Kaski

\begin{tabular}{|c|c|c|c|c|c|c|c|c|c|c|c|c|c|}
\hline $\mathrm{V} / \mathrm{G}$ & $\mathrm{AA}$ & $\overline{\mathrm{TS}}$ & $\overline{B S}$ & $\mathrm{CH}$ & $\mathrm{EN}$ & FM & $\mathrm{AF}$ & FS & $\overline{F G}$ & $\overline{\mathrm{AS}}$ & $\overline{\mathrm{AL}}$ & $\mathrm{CL}$ & $\overline{\text { Mean }}$ \\
\hline Nepal 297 & 48.50 & 8.00 & 15.75 & 0.75 & 1.50 & 0.00 & 0.00 & 0.00 & 0.25 & 0.25 & 0.00 & 0.00 & 6.25 \\
\hline Annapurna2 & 69.00 & 19.00 & 16.00 & 5.25 & 0.00 & 1.50 & 0.00 & 0.00 & 0.00 & 0.00 & 0.00 & 0.00 & 9.23 \\
\hline Lumbini & 71.50 & 8.25 & 15.25 & 7.50 & 2.25 & 6.00 & 0.00 & 0.00 & 1.50 & 0.25 & 0.00 & 0.00 & 9.36 \\
\hline Achyut & 74.25 & 14.50 & 13.00 & 11.25 & 2.25 & 0.00 & 0.00 & 3.50 & 0.00 & 0.00 & 0.00 & 0.00 & 9.90 \\
\hline Tribeni & 79.75 & 20.50 & 16.25 & 16.75 & 3.00 & 0.00 & 6.75 & 0.00 & 0.00 & 1.50 & 0.00 & 0.00 & 12.04 \\
\hline Kanti & 74.25 & 35.75 & 24.25 & 17.75 & 2.25 & 0.00 & 0.00 & 0.00 & 2.75 & 0.00 & 0.00 & 0.00 & 13.08 \\
\hline Annapurna1 & 73.75 & 43.50 & 28.00 & 13.25 & 2.25 & 1.00 & 0.00 & 0.00 & 0.00 & 0.00 & 0.00 & 0.00 & 13.48 \\
\hline BL 4061 & 73.75 & 55.50 & 31.50 & 0.00 & 1.50 & 0.00 & 0.00 & 0.00 & 0.75 & 0.25 & 0.25 & 0.00 & 13.63 \\
\hline Gautam & 74.00 & 45.25 & 30.75 & 11.50 & 2.50 & 0.00 & 0.00 & 0.75 & 0.00 & 1.25 & 0.00 & 0.25 & 13.85 \\
\hline NL 1078 & 75.75 & 22.25 & 55.00 & 14.25 & 3.00 & 0.50 & 0.00 & 2.00 & 0.00 & 0.00 & 0.00 & 0.00 & 14.40 \\
\hline
\end{tabular}

V/G: Varieties/genotypes, AA: Alternaria alternata, TS: Trichothecium sp., BS: Bipolaris sorokiniana, CH: Cladosporium herbarum, EN: Epicoccum nigrum, FM: Fusarium moniliforme, AF: Aspergillus flavus, FS: Fusarium semitectum, FG: Fusarium graminearum, AS: Acremonium strictum, AL: Alternaria longissima, CL: Curvularia lunata

Table 4 Percentage frequency of fungi in seeds of 10 wheat varieties/genotypes from Banke

\begin{tabular}{|c|c|c|c|c|c|c|c|c|c|c|c|c|c|c|}
\hline $\mathrm{V} / \mathrm{G}$ & AA & $\mathrm{BS}$ & $\mathrm{CH}$ & $\mathrm{EN}$ & FM & $\mathrm{BiS}$ & $\mathrm{CL}$ & FS & SB & AS & US & $\mathrm{AL}$ & $\mathrm{FG}$ & Mean \\
\hline BL 4341 & 86.25 & 52.50 & 8.75 & 7.75 & 3.00 & 2.50 & 0.50 & 0.00 & 0.00 & 1.25 & 0.75 & 0.00 & 0.00 & 12.56 \\
\hline NL 1171 & .50 & 60.25 & 8.00 & 3.75 & 1.50 & 1.00 & 1.00 & 0.00 & 0.00 & 0.00 & 0.00 & 0.00 & 0.00 & 12.85 \\
\hline NL 1164 & 91.50 & 61.75 & 10.25 & 8.75 & 2.25 & 1.50 & 0.00 & 0.00 & 0.00 & 0.00 & 0.00 & 0.00 & 0.50 & 13.58 \\
\hline BL 4316 & 93.25 & 54.75 & 9.00 & 7.25 & 5.75 & 4.75 & 5.50 & 0.00 & 0.00 & 0.00 & 0.00 & 0.00 & 0.00 & 13.87 \\
\hline BL 1093 & 91.00 & 73.00 & 12.50 & 6.25 & 0.00 & 0.00 & 1.25 & 0.00 & 0.00 & 0.00 & 0.00 & 0.50 & 0.00 & 14.19 \\
\hline Bhrikuti & 88.50 & 70.25 & 13.75 & 7.75 & 0.75 & 2.75 & 1.00 & 0.25 & 0.50 & 0.00 & 0.50 & 0.25 & 0.00 & 14.33 \\
\hline NL 4347 & 90.50 & 45.25 & 25.00 & 20.00 & 0.25 & 5.25 & 1.75 & 0.50 & 0.25 & 0.00 & 0.00 & 0.00 & 0.00 & 14.52 \\
\hline BL 3978 & 94.00 & 90.75 & 6.25 & 3.25 & 5.00 & 2.75 & 0.00 & 0.00 & 0.00 & 0.00 & 0.00 & 0.00 & 0.00 & 15.54 \\
\hline BL 4350 & 82.75 & 73.25 & 28.00 & 12.50 & 7.25 & 0.00 & 0.25 & 0.75 & 0.50 & 0.25 & 0.00 & 0.00 & 0.00 & 15.81 \\
\hline BL 1177 & 90.50 & 62.25 & 35.25 & 23.25 & 1.75 & 0.00 & 0.00 & 0.00 & 0.25 & 0.00 & 0.00 & 0.00 & 0.00 & 16.40 \\
\hline
\end{tabular}

V/G: Varieties/genotypes, AA: Alternaria alternata, BS: Bipolaris sorokiniana, CH: Cladosporium herbarum, EN: Epicoccum nigrum, FM: Fusarium moniliforme, BiS: Bipolaris spicifera, CL: Curvularia lunata, FS: Fusarium semitectum, SB: Stemphylium botryosum, AS: Acremonium strictum, US: Ulocladium sp. AL: Alternaria longissima, FG: Fusarium graminearum

Table 5 Percentage frequency of fungi in seeds of 10 wheat varieties/genotypes from Lalitpur

\begin{tabular}{l|ccccccccccc}
\hline V/G & AA & BS & CH & EN & US & BiS & SB & CL & FM & AS & Mean \\
\hline Pasang Lhamu & 72.25 & 10.00 & 13.50 & 7.00 & 7.50 & 0.00 & 2.50 & 0.25 & 0.00 & 0.00 & 11.30 \\
Nepal 297 & 96.25 & 18.00 & 2.25 & 1.00 & 0.00 & 2.00 & 0.50 & 0.25 & 0.00 & 0.00 & 11.95 \\
Bijaya & 97.75 & 11.75 & 6.00 & 1.75 & 0.00 & 2.50 & 0.00 & 0.25 & 0.00 & 0.00 & 12.00 \\
Achyut & 98.00 & 13.2 & 4.50 & 2.25 & 2.00 & 0.00 & 0.00 & 0.00 & 0.50 & 0.50 & 12.10 \\
WK 1204 & 99.00 & 13.50 & 8.25 & 0.00 & 0.00 & 1.50 & 0.25 & 0.00 & 0.25 & 0.00 & 12.28 \\
Annapurna 4 & 99.25 & 10.75 & 6.50 & 2.75 & 6.00 & 1.00 & 0.00 & 0.00 & 0.00 & 0.00 & 12.63 \\
RR-21 & 95.00 & 21.25 & 6.25 & 0.00 & 1.25 & 2.75 & 0.25 & 0.00 & 0.00 & 0.00 & 12.68 \\
Annapurna 1 & 97.25 & 23.50 & 5.25 & 0.50 & 0.00 & 1.00 & 1.00 & 0.25 & 0.00 & 0.00 & 12.88 \\
Bhrikuti & 93.50 & 23.25 & 11.25 & 1.00 & 0.00 & 2.25 & 0.00 & 0.75 & 0.00 & 0.00 & 13.20 \\
Gautam & 90.75 & 21.50 & 14.25 & 3.25 & 0.00 & 0.00 & 0.25 & 2.00 & 0.50 & 0.00 & 13.25 \\
\hline V/G:
\end{tabular}

V/G: Varieties/genotypes, AA: Alternaria alternata, BS: Bipolaris sorokiniana, CH: Cladosporium herbarum, EN: Epicoccum nigrum, US: Ulocladium sp., BiS: Bipolaris spicifera, SB: Stemphylium botryosum, CL: Curvularia lunata, FM: Fusarium moniliforme, AS: Acremonium strictum 
Table 6 Percentage frequency and relative abundance of fungi in forty seed samples from four locations.

\begin{tabular}{l|cccccccc}
\hline \multirow{2}{*}{ Fungi } & \multicolumn{4}{|c}{ Frequency $(\%)$} & \multicolumn{4}{c}{ Relative abundance $(\%)$} \\
\cline { 2 - 7 } & Lalitpur & Chitwan & Kaski & Banke & Lalitpur & Chitwan & Kaski & Banke \\
\hline Bipolaris sorokiniana & 16.68 & 18.93 & 24.57 & 64.40 & 13.32 & 32.40 & 17.20 & 34.69 \\
Alternaria alternata & 93.90 & 26.10 & 71.50 & 89.97 & 76.00 & 40.40 & 55.10 & 49.11 \\
Cladosporium herbarum & 7.80 & 0.08 & 9.80 & 15.70 & 6.03 & 0.12 & 6.44 & 7.91 \\
Bipolaris spicifera & 1.30 & 4.50 & 0.00 & 2.05 & 0.99 & 5.72 & 0.00 & 1.10 \\
Fusarium moniliforme & 0.13 & 0.10 & 0.90 & 2.80 & 0.39 & 0.22 & 0.66 & 1.36 \\
Curvularia lunata & 0.38 & 1.48 & 0.03 & 1.12 & 0.09 & 3.43 & 0.01 & 0.62 \\
Fusarium semitectum & 0.00 & 0.00 & 0.62 & 0.15 & 0.00 & 0.00 & 0.43 & 0.09 \\
Fusarium graminearum & 0.00 & 0.03 & 0.53 & 0.05 & 0.00 & 0.03 & 0.37 & 0.03 \\
Stemphylium botryosum & 0.47 & 0.00 & 0.00 & 0.15 & 0.29 & 0.00 & 0.00 & 0.09 \\
Aspergillus flavus & 0.00 & 6.20 & 0.68 & 0.00 & 0.00 & 7.40 & 0.46 & 0.00 \\
Rhizopus sp. & 0.00 & 6.70 & 0.00 & 0.00 & 0.00 & 7.90 & 0.00 & 0.00 \\
Penicillium sp. & 0.00 & 0.68 & 0.00 & 0.00 & 0.00 & 1.06 & 0.00 & 0.00 \\
Aspergillus niger & 0.00 & 0.60 & 0.00 & 0.00 & 0.00 & 0.68 & 0.00 & 0.00 \\
Trichothecium sp. & 0.00 & 0.00 & 27.20 & 0.00 & 0.00 & 0.00 & 17.82 & 0.00 \\
Epicoccum nigrum & 1.95 & 0.65 & 2.05 & 10.10 & 1.56 & 0.73 & 1.33 & 4.83 \\
Ulocladium sp. & 1.68 & 0.00 & 0.00 & 0.13 & 1.31 & 0.00 & 0.00 & 0.07 \\
Acremonium strictum & 0.05 & 0.00 & 0.35 & 0.15 & 0.39 & 0.00 & 0.23 & 0.07 \\
Alternaria longissima & 0.00 & 0.00 & 0.03 & 0.08 & 0.00 & 0.00 & 0.02 & 0.04 \\
Mean & 6.91 & 3.67 & 7.68 & 10.38 & 5.58 & 5.56 & 5.56 & 5.56 \\
\hline
\end{tabular}

Among the weak pathogens, incidence of A. alternata was maximum in all locations with a mean frequency and relative abundance of $70.37 \%$ and $55.15 \%$, respectively (Table 6), while incidence of other non pathogenic and weakly pathogenic mycoflora was negligible (less than $9.00 \%$ ). Among the storage fungi, prevalence of Aspergillus flavus and Rhizopus spp. was high in Chitwan and negligible at other locations. This reflects the storage condition in which seeds are kept. Bashir and Kutama (2012) reported that prevalence of storage fungi could be due to poor method of storage. (i.e. high temperature and high RH) or contaminated farm equipments or soil. Bipolaris spicifera, Cladosporium herbarum, Curvularia lunata, Epicoccum nigrum, Stemphyliumbotryosum, Ulocladium sp., Acremonium strictum, Alternaria longissima and Trichothecium sp. are weak parasitic and saprophytic fungi. Most of these fungi cause sooty head molds. Hershman (2011) mentioned that wet and humid weather during the latter stages of grain development and crop maturation results in development of head mold fungi on senescing and damaged wheat heads. Cultural practices also increase the inoculum of seed borne mycoflora. Vrandečićet al. (2013) reported that the number of grains infected with Fusarium species were significantly lower with conventional tillage compared to reduced tillage. Suproniene et al. (2011) reported increase in grain infection by Alternaria, Aspergillus and Cladosporium species under no tillage condition. High fertilizer rates also resulted in an increase in grain infection by Fusarium and Penicillium species. Removal of the previous crop straw from the fields helps to decrease the fungal infection in cereals (Suproniene et al., 2011).

Mean frequency of all mycoflora was also highest in Banke $(10.38 \%)$, while relative abundance was similar in all 4 locations (i.e.3.87\% to 5.58\%). According to
Duveiller and Gilchrist (1994), Salgado et al. (2011) and Wiese (1987), the most important seed borne fungal diseases of wheat were Helminthosporium leaf blight (caused by Bipolaris sorokiniana and Pyrenophora triticirepentis), Fusarium head blight (incited by Fusarium spp.) and Black point/smudge (caused by Alternaria, Fusarium, Cochliobolus, Aspergillus, Cladosporium, Penicillium, Rhizopus and Stemphylium).

\section{Conclusion}

Nepalese wheat seeds found to be associated with many fungi, but their presence varied with varieties/genotypes and locations. The study indicated that wheat seeds should be produced in areas with relatively lower temperature and relative humidity for low seed infection with fungi.

\section{Acknowledgement}

The authors heartily acknowledge Seed Quality Control Centre, Hariharbhawan, Lalitpur for providing research laboratory for work, and National Maize Research Program, Rampur, Chitwan; Regional Agricultural Research Stations, lumle, Kaski and Khajura, Banke, and National Agricultural Research Council, Khumaltar, Lalitpur, for providing wheat seeds of various varieties/genotypes for the study.

\section{References}

Alam KB, Saha NK. 1991. Helminthosporium leaf blight of wheat a new problem in Bangladesh. Paper presented at international Workshop on Helminthosporium blight. CIMMYT, Mexico, D. F. 12 pages.

Barabara K, Mona T, Estein S, Birgitte A. 2004. Alternaria and Fusarium in Norwegain grains reduced quality -a matched pair sample study. Int. J. Food Microbiology. 93: 51-62. 
Bashir, M. Mani MA, Kutama AS. 2012. Seed-borne mycoflora of local and improved wheat (Triticum aestivum L.) cultivars in Kano, Nigeria. Bayero Journal of Pure and Applied Sciences. 5: $101-103$.

Bateman GL, Kwasna H. 1999. Effects of number of winter wheat crops grown successively on fungal communities on wheat roots. Applied Soil Ecology. 13: 271-82.

Clear RM, and Patrick'Can SK. 1993. Prevalence of some seed borne fungi on soft white winter wheat seed from Ontario, Canada. Plant Disease Survey. 73: 143-149.

Dexter JE, Clear RM, and Preston KR. 1996. Fusarium head blight: effect on the milling and baking of some Canadian wheats. Cereal Chemistry. 73: 695-701.

Duveiller E, Gilchrist L. 1994. Production constraints due to Bipolaris sorokiniana in wheat: Current situation and future prospects. In: Saunders DA, Hettel GP (ed.) Wheat in HeatStressed Environments: Irrigated, DryAreas and Rice-Wheat Systems. CIMMYT, Mexico D.F. pp. 343-352.

Fakhrunnisa, M. H. Hashmi and A. Ghaffar. 2006. Seed-borne mycoflora of wheat, sorghum and barley. Pakistan Journal of Botany. 38: 185-192.

Friis-Hansen E. 1995. Seeds for African peasants: Peasants' needs and agricultural research - the case of Zimbabwe. The Nordic African Institute. 227 pages.

Hershman, D. E. 2011. Black "sooty" head mold of wheat.University of Kentucky. Plant Pathology Fact Sheet.

Khanal NP, Maharjan KL, Sapkota A. 2012. Technical efficiency in wheat seed production: A case study from terai region of Nepal. J. Int. Dev. coop., 19: 41-50.

Khanzada KA, Rajput MA, Shah GS, Lodhi AM, Mehboob F. 2002. Effect of seed dressing fungicides for the control of seed borne mycoflora of wheat. A. J. Pl. Sci., 1: 441-444.

Mathur SB, Kongsdal O. 2003. Common laboratory seed health testing methods for detecting fungi $\left(1^{\text {st }}\right.$ ed). ISTA.

MOAD. 2013. Selected indicators of Nepalese agriculture and population.
Nafula MM. 1997. Assessment of seed borne pathogens for some important crops in western kenya. KARI-Katumani, PO Box, 340-90100.

Naqvi SDY, Shiden T, Merhawi W, Mehret S. 2013. Identification of seed borne fungi on farmer saved sorghum (Sorghum bicolor L.), pearl millet (Pennisetum glaucum L.) and groundnut (Arachis hypogaea L.) seeds. Agr. Sci. Res. J., 3: 107-114.

Pickett LS, Pruitt JD. 2010. Non-chemical methods for controlling diseases in the home landscape and garden. Oklahoma cooperative extension fact sheets available on website: http://osufacts.okstate.edu

Rosyara UR. 2002. Physio-morphological traits associated with resistance and tolerance to Helminthosporium leaf blight in spring wheat. M. Sc. Thesis, Tribhuvan University, Department of Plant Breeding, IAAS, Chitwan, Chitwan, Nepal. P. 2.

Saari EE. 1998. Leaf blight disease and associated soil borne fungal pathogens of wheat in South and Southeast Asia. In: Duveiller E, Dubin HJ, Reeves J, McNab A(ed.) Helminthosporium Blights of Wheat: Spot Blotch and Tan Spot. CIMMYT, Mexico D.F. pp. 37-51.

Salgado JD, Wallhead M, Madden LV, Paul PA. 2011. Grain harvesting strategies to minimize grain quality losses due to Fusarium head blight in wheat. Plant Dis. 95: 1448-1457.

Suproniene S, Mankeviciene A, Kadziene G. 2011.The effect of different tillage-fertilization practices on the mycoflora of wheat grains. Agricultural and Food Science. 20:315-326.

Vrandečić K, Jug D, Ćosić J, Stošić M, Ilić J. 2013. The impact of tillage and fertilization on wheat grain infection. In: $\mathrm{V}$. Vukadinović and B. Đurđević (ed.) proceedings of 2nd International Scientific Conference on Soil and Crop Management: Adaptation and Mitigation of Climate Change, 26-28 Sept.2013. Osijek, Hrvatska. pp. 296-301.

Warham EJ, Butler LD, Sutton BC. 1996. Seed testing of maize and wheat: A laboratory guide. CIMMYT, Mexico. P. 84.

Wiese MV. 1987. Compendium of Wheat Diseases $\left(2^{\text {nd }}\right.$ ed). The American Phytopathological Society, St Paul. USA. 